\title{
To the Problem of Language World Picture in Russian Current Cultural Linguistics
}

\author{
Alesia I. Frantceva \\ St. Petersburg State University, Universitetskaya nab., 7/9, St. Petersburg, 199034, St. Petersburg, \\ Russian Federation
}

Email: st053400@student.spbu.ru

Keywords: Linguistics, Concept, Cultural Linguistics.

\begin{abstract}
This paper focuses on the interaction of language and culture and cultural linguistics studies. The paper related to this problem. The problems of studying the concept entered the science recently, which indicates the novelty and relevance of the study. This field of science was widely studied in the late 20th century among linguists. The result of a wide study was to develop methodological model of Z. D. Popova, I. A. Sternin. Thus, the material of this research is cultural codes-concepts in the studied language. This paper revealed the correlation of concepts-cultural codes and language world picture. We have considered the basic concepts of world pictures. The purpose of this paper is to construct a model of cultural linguistics analysis, used in the study of concepts. The paper concludes that the interaction of language and culture is inseparable. Only after studying the cultural codes-concepts and reflected in the language the world picture, we can approve the understanding of the language.
\end{abstract}

\section{Introduction}

Cultural linguistics is a field of studies, researching interaction and interrelation of culture and language in its functioning and reflecting this process as a holistic structure in both language and out-of-language cultural content. Cultural linguistics studies the ways of interaction between language and culture. It also studies speech behavior, correlation of language and religion, speech etiquette and text, as a cultural unit. The article focuses on the basic methodological approaches and the models of cultural linguistics analysis, as well as the methods of the research of this issue.

\section{The connection of culture and language in the cultural linguistics approach and the models of the cultural linguistics analysis}

The connection of culture and language is widely researched by the Russian linguists, such as D. Arutyunova, V. V. Vorobyev, E. I. Zinovyeva, V. A. Maslova, Y. S. Stepanov, V. N. Teliya, V. M. Shaklein, E. E. Yurkov and others. Due to their work cultural linguistics has become an independent field of studies nowadays.

The issues connected with the research of specifics of the language world picture of a certain nation or language mentality have become widely investigated. It has become obvious now that a person lives not only in a cultural space of his nation but also in the mental space of the language he speaks.

Determining the status of cultural linguistics among other fields of studies, connected with language, E. I. Zinovyeva and E. E. Yurkov admit that "cultural linguistics is a theoretical philological discipline, which studies different ways of how the knowledge about the world is expressed by a native speaker of a certain language, by the means of analysis of various language units of different levels, speech, speech behavior, discourse, which is meant to describe these objects so that it could disclose the meaning of the analyzed units, its shades, connotations. The development of the criteria for choosing these is one of the problems, being solved by cultural linguistics" [1]. According to E. I. Zinovyeva and E. E. Yurkov the aim of cultural linguistics is the 
description and the explanation of the language features and its functioning as a phenomenon conditioned by culture.

Thus, cultural codes, depicted in language, including concepts, reflect the mentality of a nation, expressed in the language world picture, which is the set of a person's ideas of the world. Cultural codes - the concepts, which should be studied on the base of the modern methodological approaches and the models of the cultural linguistics analysis - are the field of research for cultural linguistics [2].

Taking into attention that to study concept via language is the easiest and the most available way to understand the content of the concept, it is relevant to consider one of the most common and the most widely used methodological models of the concept analysis.

The model by Z. D. Popova and I. A. Sternin includes the following stages:

- historical and etymological analysis,

- lexicographical description of the word-name of the concept,

- the detection of the conceptual features, which form the notional base of the concept,

- the analysis of a word-formation nest,

- the analysis of the concept image, the analysis of the concept value.

This model allows to make a thorough analysis of the researched concept in a certain language and to detect the typical features.

In Russian Linguistics several interpretations of the term language world-picture are accepted:

- the system of internal ideas of the reality: the set of the whole material environment, the world, which is perceived by our sense organs independent of our consciousness, the system of views, mediated by the language spoken by a certain ethnicity [3];

- the interconnection between the language and the way of thinking [4];

- the world perception through the prism of the language [5];

- The language world picture is defined as "a scheme of the world perception, fixed in a language and specific for the certain language group" by E. S. Yakovleva, who developed the ideas of A. G. Shmelev. This definition will be used in the article [6].

\section{The term of world picture}

Linguists suggest that the problem of the language world picture is connected with the fundamental issue of the display of life via language. The main question, which leads to controversies among the researchers is if a person perceives the reality by logical categories, not connected with language or via language.

"National specificity comes not from the language but from the actual reality, the language on the other hand is merely reflected in its semantics and detects the differences, which are communicatively relevant for the people for some reasons or others" [7].

Thus a certain individual, a language personality simultaneously forms the language world picture and uses the language world picture, which was and is being formed by his nation, the ethnicity he belongs to.

\section{The terms of naive, conceptional and scientific world picture}

It is also common in cultural linguistics studies to distinguish naive, conceptional and scientific world pictures. An average native speaker perceives the reality. Though his ideas are personal, individual, they are based on the ideas of other native speakers, and also on the ideas, which have being formed for centuries and have been printed in the language memory of the nation. Such language ideas form the naive world picture.

According to Y. D. Apresyan, naive world picture is defined as the idea of the world specific for an average language speaker based on the prescientific general concepts, coming to his disposal via the language" [8]. 
At the same time a person perceives, realizes and interprets the world. These processes are reflected in the language. Therefore the main function of the world picture is considered as the conceptualization of the reality. The conceptional world picture includes the ability of an individual, a language personality for conceptualisation and categorization of the internal and the external world, his ability to sort and classify his knowledge.

In the history of formation of any discipline of scientific knowledge it is possible to distinguish the basic periods of development and, primarily, the prescientific period, when people used the ideas and usual words, naming these ideas, and the scientific period, when people started to use the ideas and terms.

The researchers mention the differences between the scientific and the usual (naive) world picture. For instance, O.A. Kornilov, distinguishing different types of language world picture defined the scientific world picture as "the collective knowledge of the world including the society nature and a human as a social being" [9].

Thus naive, conceptual and scientific world picture complement each other. Only having examined all of them it is possible to speak of a specific for a certain nation vision of the world, created by and reflected in the language. The study of lexis takes a specific part in the study of the language world picture. The research of the global world picture, universalism, is combined from the knowledge about local world pictures.

\section{The local world picture as a part of the language world picture}

One of the interesting parts of the language world picture is the local world picture. The local world picture can be formed by words, important for certain ethnicity. The major layer of such words are key lexemes of the culture. Such lexemes are first of all concepts. To describe the local world picture the concepts are thoroughly examined and described. Besides concepts, cultural linguists study lexico-semantic groups of words, phraseological units, lexico-semantic and phrase-semantic fields. All of these give an idea of a language world picture, specific for a certain nation . The universal world picture, typical for the ethnicity, is formed by local, partial pictures of the world.

\section{The term of the literary world picture}

If to mention basic categories of cultural linguistics research, it is necessary to distinguish the term of the literary world picture. The Russian researchers in the field of stylistics from SaintPetersburg, disciples and followers of B. A. Larin, examining the word functioning in the literary text, in semantic-stylistic system of a writer, have been developing the notions, connected with the reflection of the world in the text. One of the results of the group activity has been the book by D. M. Potsepnya "The image of the world in the word of the writer" [10]. Saint Petersburg stylists suggest that the author's world picture is reflected in the word semantics of a text. The most important words for a writer are: keywords, motives, concepts - they gain in the text a special meaning. The author's vision of the world is expressed most distinctly in the aesthetic meaning of a word-concept, the semantics of which can differ from the general one. However, the language meaning is the platform on which the conversions of this meaning take place.

\section{Summary}

To conclude, symbol-concept in the text, in the work of a certain author reflects not only the author's view but also the language world picture of a linguocultural group, to which the author belongs. The symbol concept playing an important part in the work of a certain author is closely connected with the language concept, it is so to say the kind of the latter. Therefore it is possible to make conclusions on the base of the study of symbol-concepts in the work of writers about the deep semantics, the sense content of a language concept. And via the language concept it is possible to conclude on the language mentality and the mentality of a nation, for concept is the indicator of it. 
The problem of language world picture is a basic part the cultural linguistics research. Only having examined the range of problems connected with concept, the part of a cultural code of the mentality of a certain nation, it is possible to speak of understanding of the world picture, typical for a certain ethnicity.

\section{References}

[1] Zinovyeva E. I., Yurkov E. E. Linguoculturologia [Cultural Linguistics] / E. I. Zinovyeva, E. E. Yurkov // Saint-Petersburg: MIRS, 2006. - P. 16-18. [in Russian].

[2] Frantceva A. I. K voprosu o lingvokulturologicheskyh issledovaniah i ih osnovnyh metodah (na primere kontsepta "bashnya" $\mathrm{v}$ cheshskom i angliyskom yazykah na fone russkogo yazyka) [To the problem of cultural linguistics researches and their main methods (on the example of the concept "tower" in Czech and English against the background of the Russian language)] / A. I. Frantceva // Vestnik Sankt-Peterburgskogo universiteta [Bulletin of Saint-Petersburg State University]. - St.Petersburg: Saint-Petersburg State University, 2012. - s.9 No. 1. - P. 147-151. [in Russian].

[3] Rudnev V. P. Enciklopedicheskiy slovar kultury XX veka [Encyclopedic dictionary of the culture of XX century] / V. P. Rudnev // Moscow: Agraf, 2001. P. 175-180. [in Russian].

[4] Shmelev A. D. Russkaya yazykovaya kartina mira: materialy k slovaru [Russian linguistic picture of the world: material for the dictionary] / A. D. Shmelev // Moscow: Languages of Slavic culture, 2001. P. 176-178. [in Russian].

[5] Yakovleva E. S. Opisaniye yazykovoy kartiny mira [The description of the linguistic picture of the world] / E. S. Yakovleva // Russkiy yazyk zarubezhom [Russian language abroad]. Moscow: State Institute of Russian language named after A. S. Pushkin, 1996. No. 1-3. - P. 1316. [in Russian].

[6] Yakovleva E. S. Fragmenty russkoy yazykovoy kartiny mira (modeli prostranstva, vremyeni i vospriyatiya) [Fragments of Russian picture of the world (models of space, time and perception)] / E. S. Yakovleva // Moscow: Gnozis, 1994. - P. 9-17. [in Russian].

[7] Sternin I. A., Bykova G. V. Kontsepty i lakuny. Yazykovoe soznaniye: formirovanie i funkcionirovanie [Concepts and lacunas. The linguistic consciousness: formation and functioning] / I. A. Sternin, G. V. Bykova // Moscow, 2000. - P. 55-67. [in Russian].

[8] Apresyan Y. D. Izbrannye trudy. V 2 t. [Selected works. In 2 volumes] / Y. D. Apresyan // Moscow: East literature, 1995, vol.1. - P. 57-59. [in Russian].

[9] Kornilov O. A. Yazykovye kartiny mira kak proizvodnye nacionalnyh mentalitetov [Linguistic picture of the world as derivatives of national mentalities] / O. A. Kornilov // Moscow: MGU Publ., 1999. [in Russian].

[10] Potsepnya D. M. Obraz mira v slove pisatelya [Image of the world in the word of the writer] / D. M. Potsepnya // Saint-Petersburg, 1997. - 261 p. [in Russian]. 